\title{
Total aerosol effect: radiative forcing or radiative flux perturbation?
}

\author{
U. Lohmann ${ }^{1}$, L. Rotstayn ${ }^{2}$, T. Storelvmo ${ }^{1}$, A. Jones ${ }^{3}$, S. Menon ${ }^{4}$, J. Quaas ${ }^{5}$, A. M. L. Ekman ${ }^{6}$, D. Koch ${ }^{7}$, and \\ R. Ruedy ${ }^{7}$ \\ ${ }^{1}$ Institute of Atmospheric and Climate Science, ETH Zurich, Switzerland \\ ${ }^{2}$ Centre for Australian Weather and Climate Research, CSIRO, Aspendale, Victoria, Australia \\ ${ }^{3}$ Met Office Hadley Centre, Exeter, UK \\ ${ }^{4}$ Lawrence Berkeley National Laboratory, Berkeley, USA \\ ${ }^{5}$ Max Planck Institute for Meteorology, Hamburg, Germany \\ ${ }^{6}$ Stockholm University, Stockholm, Sweden \\ ${ }^{7}$ NASA GISS, New York, NY, USA
}

Received: 15 October 2009 - Published in Atmos. Chem. Phys. Discuss.: 30 November 2009

Revised: 16 March 2010 - Accepted: 30 March 2010 - Published: 6 April 2010

\begin{abstract}
Uncertainties in aerosol radiative forcings, especially those associated with clouds, contribute to a large extent to uncertainties in the total anthropogenic forcing. The interaction of aerosols with clouds and radiation introduces feedbacks which can affect the rate of precipitation formation. In former assessments of aerosol radiative forcings, these effects have not been quantified. Also, with global aerosol-climate models simulating interactively aerosols and cloud microphysical properties, a quantification of the aerosol forcings in the traditional way is difficult to define properly. Here we argue that fast feedbacks should be included because they act quickly compared with the time scale of global warming. We show that for different forcing agents (aerosols and greenhouse gases) the radiative forcings as traditionally defined agree rather well with estimates from a method, here referred to as radiative flux perturbations $(R F P)$, that takes these fast feedbacks and interactions into account. Based on our results, we recommend $R F P$ as a valid option to compare different forcing agents, and to compare the effects of particular forcing agents in different models.
\end{abstract}

\section{Introduction}

Aerosols affect climate directly by scattering and absorption of shortwave and thermal radiation (direct aerosol effect (DAE)). While most aerosol particles, such as sulfates

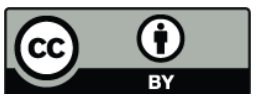

Correspondence to: $\mathrm{U}$. Lohmann (ulrike.lohmann@env.ethz.ch) and sea salt, mainly scatter solar radiation, black carbon also strongly absorbs solar radiation. Regardless of whether the aerosols absorb or scatter radiation, less solar radiation penetrates to the surface. The global-mean net direct effect at the top-of-the-atmosphere (TOA) is a cooling that partly offsets the warming due to greenhouse gases. It is estimated as $-0.5 \mathrm{~W} \mathrm{~m}^{-2}$ with a 5 to $95 \%$ confidence range of -0.1 to $-0.9 \mathrm{~W} \mathrm{~m}^{-2}$ (Forster et al., 2007). In addition, aerosols modify the radiation budget indirectly by acting as cloud condensation nuclei and ice nuclei. The cloud albedo enhancement (first indirect aerosol effect (IAE), cloud albedo effect or indirect aerosol forcing) of warm stratiform clouds refers to an increase in cloud droplet number concentration due to anthropogenic aerosols for a constant liquid water content (Twomey, 1977). These more numerous and smaller cloud droplets increase the total droplet surface area and thus cloud albedo. The cloud albedo effect can be calculated as a forcing because of the assumption of a constant liquid water content. Ensemble-averaged global-mean model estimates of the cloud albedo effect have remained rather constant over time (see Fig. 1) and amount to roughly $-0.9 \mathrm{~W} \mathrm{~m}^{-2}$. The $-0.9 \mathrm{~W} \mathrm{~m}^{-2}$ estimate that is obtained from the average over all published estimates, treating each of them equal (one paper one vote) is slightly stronger than the estimate of the cloud albedo effect in the fourth assessment report of the Intergovernmental Panel on Climate Change (IPCC) where a different weighting procedure was used. There the median value of the indirect aerosol forcing was estimated as $-0.7 \mathrm{~W} \mathrm{~m}^{-2}$ with a 5 to $95 \%$ range of -0.3 to $-1.8 \mathrm{~W} \mathrm{~m}^{-2}$ (Forster et al., 2007). The rather large uncertainty in both the direct and indirect (cloud albedo effect) forcing accounts for a large fraction of the uncertainty in the total anthropogenic

Published by Copernicus Publications on behalf of the European Geosciences Union. 


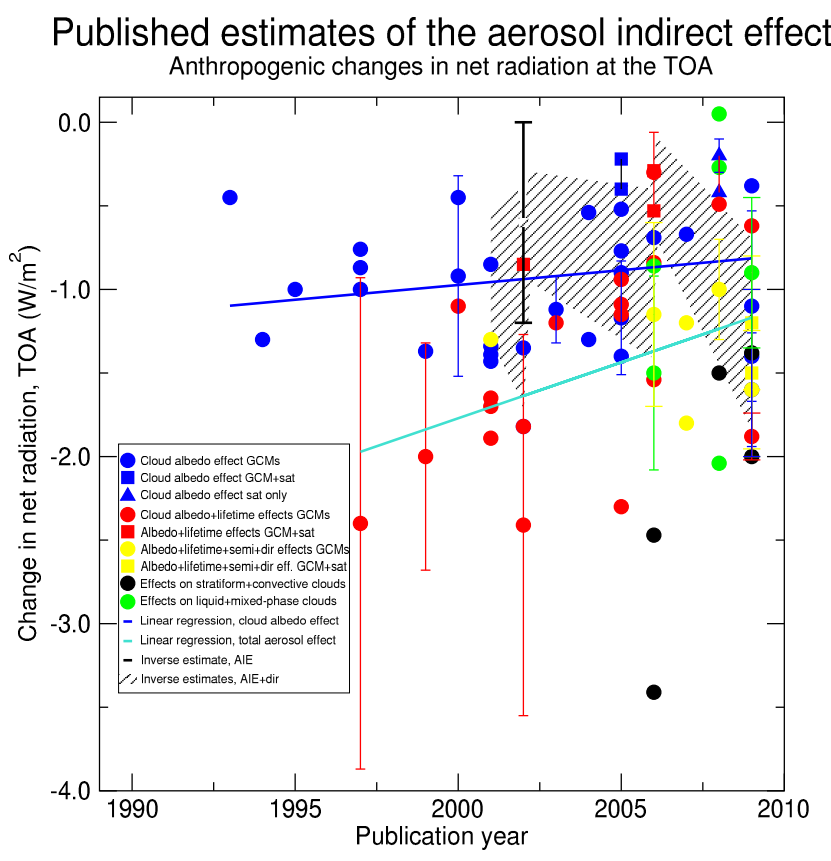

Fig. 1. Model, satellite and inverse estimates of the aerosol indirect effects over the last two decades. For each method or effect considered, each symbol represents one published estimate (one paper one vote). Blue represents estimates of the cloud albedo effect from GCMs (dots), GCMs combined with satellite measurements (squares) and satellite estimates only (triangles). Red represents estimates of both the cloud albedo and cloud lifetime effect from GCMs (dots) and GCMs combined with satellite estimates (squares). The yellow dots represent estimates of the combined cloud albedo, lifetime, direct and semi-direct effects. Black dots represent the aerosol effects on stratiform and convective clouds and green dots represent estimates of aerosol effects on liquid and mixed-phase clouds. The black stippled area refers to inverse estimates. In case of multiple estimates per paper, the vertical bars denote the standard deviation. See appendix for the individual papers, from which the estimates are obtained.

forcing (Kiehl, 2007; Forster et al., 2007; Haywood and Schulz, 2007).

In addition to the cloud albedo effect, there are multiple other effects of aerosols on clouds such as the cloud lifetime effect, the semi-direct effect and aerosol effects on mixedphase, convective and cirrus clouds (Lohmann and Feichter, 2005; Denman et al., 2007). However, these effects cannot be evaluated via the usual definition of radiative forcing as the instantaneous change in radiative flux caused when the forcing agent is imposed, because these effects do not act "instantaneously". The semi-direct effect refers to the effect of absorbing aerosols on clouds. Absorbing aerosols can change the thermal structure of the atmosphere and can cause evaporation of cloud droplets due to their heating of the air (Hansen et al., 1997; Ramanathan et al., 2001). Hansen et al. (1997) showed that for any change in vertical heating of the atmosphere, the top-of-the-atmosphere radiative forcing is not representative, as it could have a zero effect at the topof-the-atmosphere, but cause a radiative effect at the surface.

If aerosols and/or cloud droplet number concentrations are calculated interactively in the model, the calculation of the aerosol radiative forcing is not straightforward because aerosols will then also influence the precipitation formation and thereby cause an additional change in cloud properties. Hence these effects are usually evaluated as a radiative flux perturbation (RFP) (Haywood et al., 2009). The RFP is calculated as the difference in the top-of-the-atmosphere radiation budget between a present-day simulation and a preindustrial simulation, both using the same sea surface temperatures. RFP estimates thus include fast changes and interactions in the climate system that induce changes in the meteorology. "Fast" means here that the changes act quickly as compared with the time scale of global warming. "Fast" is considered here as a time scale of less than a few years. This does not conform to the pure definition of an instantaneous radiative forcing (Forster et al., 2007), in which only one radiatively active agent is changed, while leaving tropospheric profiles of temperature and other variables constant.

The issue of how to define radiative forcings is not new. Forcing aims to estimate the influence of a particular climate perturbation on equilibrium global-mean surface temperature change, hence allowing comparison of different perturbations without the need to actually conduct equilibrium climate-change simulations. The concept of radiative forcing has been gradually refined, due to limitations that were found with the original idea of instantaneous radiative forcing. For forcing agents that affect stratospheric temperature, such as $\mathrm{CO}_{2}$ and ozone, the procedure recommended by IPCC is to allow stratospheric temperatures to adjust to the imposed forcing agent (a process that takes a few months), before calculating the "adjusted" forcing at the tropopause (Shine et al., 1995). For increases of $\mathrm{CO}_{2}$, this adjustment cools the stratosphere, reducing the net downwards flux at the tropopause by order 10\% (Hansen et al., 2005). For stratospheric ozone depletion, omission of the adjustment can change the sign of the forcing from negative to positive (Shine et al., 1995; Hansen et al., 2005). Thus for ozone in particular, the stratospheric adjustment is essential if the radiative forcing is to be of any use as a predictor of the induced change in global-mean surface temperature.

More recent studies have shown that using the adjusted radiative forcing, the change in surface temperature per unit forcing, or climate sensitivity, is not strictly the same for different perturbations. To account for this, one approach suggested by Joshi et al. (2003) and Hansen et al. (2005) is to obtain an efficacy $(E)$ and to display it next to forcing estimates. $E$ is defined as the ratio of the climate sensitivity parameter for a given forcing agent to the climate sensitivity parameter for $\mathrm{CO}_{2}$. E can vary markedly for different forcing agents and for different models, depending on how the forcing projects onto the various feedback mechanisms; see 

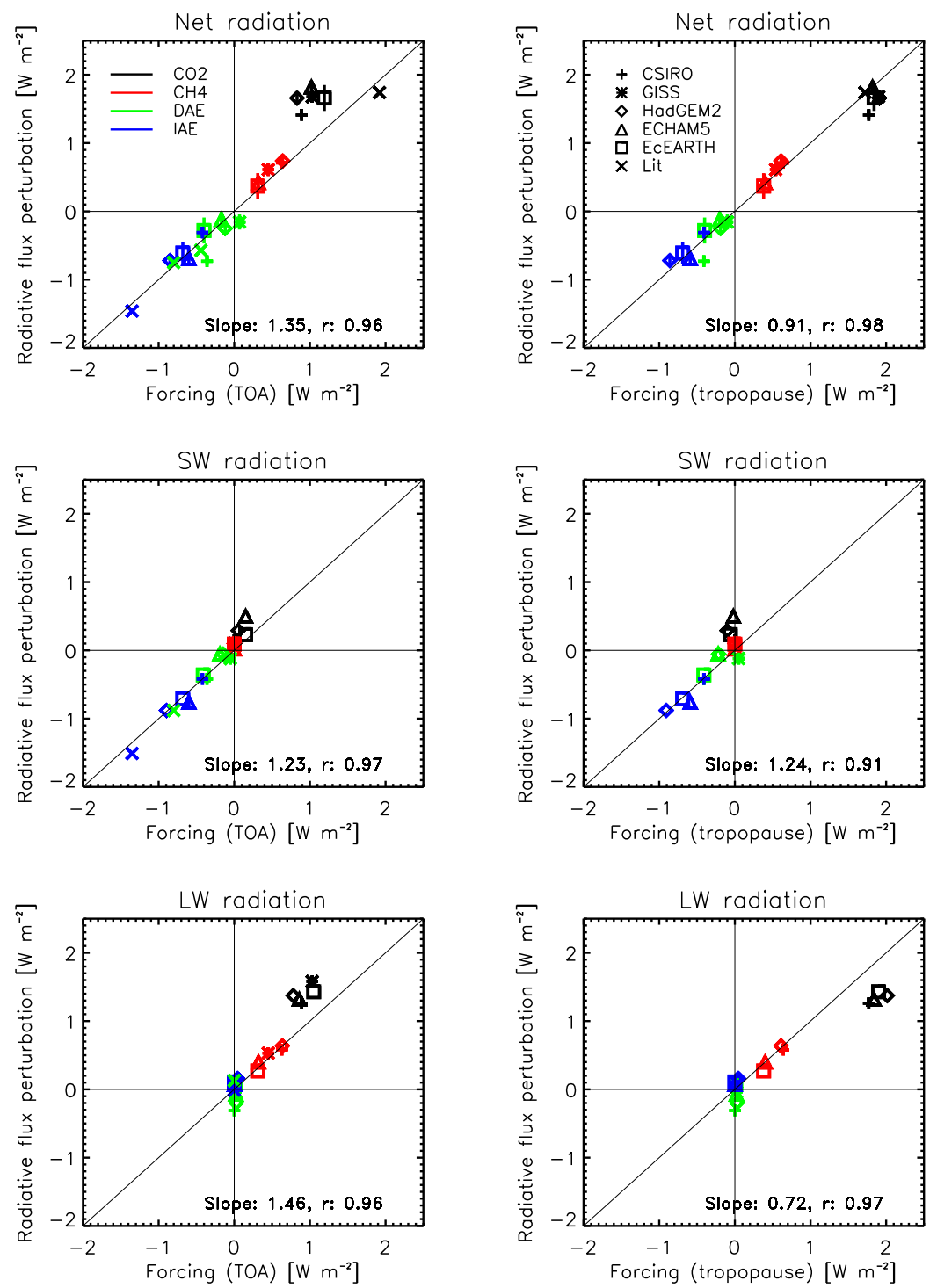

Fig. 2. Net, shortwave and longwave radiative flux perturbation $(R F P)$ versus top-of-the-atmosphere (TOA) and tropopause forcing $(F)$, respectively, from five GCMs. Vertical bars denote the interannual standard deviation in the radiative flux perturbation calculations. The slope of the least square fit through the data as well as the correlation coefficient $r$ are shown at the bottom. $R F P$ vs. $F$ values from the literature (Rotstayn and Penner, 2001; Hansen et al., 2005) are added as well.

Forster et al. (2007) for a review. In particular, their Fig. 2.19 shows that for "realistic" perturbations of forcing agents in GCMs, $E$ generally lies in the range of 0.6 to 1.3 . The outlying point with $E \sim 1.65$ in that figure was derived by normalising the change in the global mean surface temperature $(\Delta T)$ obtained by Rotstayn and Penner (2001) in response to the combined cloud-albedo and lifetime effects by the forcing they calculated for the cloud-albedo effect only. If instead $\Delta T$ is normalised by the RFP estimated by Rotstayn and Penner (2001) for the combined effects, $E=0.86$ is obtained, in good agreement with the value of 0.83 they obtained for the cloud-albedo effect when it was calculated as an instantaneous forcing. This shows that the adjusted forc- ing concept does not work especially well for simulations that include indirect effects beyond the cloud-albedo effect. Further, the linear forcing-response concept may break down for certain idealized perturbations, especially involving absorbing aerosols. Aerosols within a certain range of single scattering albedo can even have negative adjusted forcing but induce a global-mean warming, i.e. $E$ can be negative (Forster et al., 2007).

In the last few years, several studies have investigated yet another method of calculating radiative forcing, mainly in the context of $\mathrm{CO}_{2}$ (Gregory et al., 2004; Forster and Taylor, 2006; Gregory and Webb, 2008; Andrews and Forster, 2008). The method is to regress the top-of-atmosphere radiative flux 
$(N)$ against the global-mean surface air temperature change $(\Delta T)$. The forcing is taken as the intercept of the regression line, i.e. as the value of $N$ when $\Delta T=0$. An interesting aspect of this method is that the efficacy is included in the forcing estimate (Forster and Taylor, 2006). Another important outcome from this work is that "fast feedbacks", such as cloud changes that respond directly to the forcing of $\mathrm{CO}_{2}$ rather than to $\Delta T$, are now regarded as part of the forcing (Gregory and Webb, 2008; Andrews and Forster, 2008). The "feedbacks" are considered to be those that operate on longer time scales (those on which $T$ changes), and can be expressed as functions of $\Delta T$. "Long" time scales in this context refer to time scales larger than several years if only the mixed layer of the ocean is considered, or more than centuries if the full ocean is coupled to the atmospheric GCM (Gregory and Webb, 2008).

These conclusions are similar to those that have arisen in aerosol modelling, where it also seems desirable to treat "fast feedbacks" as part of the forcing. We note that the regression method may be useful for the evaluation of aerosol forcings in atmospheric models, but it also requires a mixed-layer or full ocean model, which not all groups have access to. A modification of the RFP method, in which land-surface temperature is fixed in addition to sea-surface temperature, was used by Shine et al. (2003) in an intermediate complexity GCM. "Intermediate" refers here to parameterizations that would have been state of the art in the 1980s. Because they are simpler, the computational costs are lower, allowing a wider set of calculations to be performed. However, fixing land-surface temperature is difficult in a full GCM that includes a diurnal cycle. In this study we focus on the RFP method, which is straightforward to calculate in most global aerosol models.

Two questions arise about the RFP method: (1) Is it a valid approach for comparing aerosol effects that include fast feedbacks and interactions (cloud lifetime effect, semi-direct effect or aerosol interactions with mixed-phase and ice clouds) with other forcings such as those from the well-mixed greenhouse gases (GHG), and (2) Can it be used for comparing these aerosol effects between different models?

The difference between the forcing (as traditionally defined) and the RFP due to the aerosol indirect effect was first investigated by Rotstayn and Penner (2001). They found from their atmospheric GCM coupled to a mixed layer ocean model that the differences in the climate sensitivity due to using the RFP method were smaller than the differences in the climate sensitivity due to different forcings. They hence argued that RFP estimates from aerosols should be compared to forcing estimates from GHG. The utility of the RFP method was further explored for a range of forcing agents by Hansen et al. (2002, 2005), also in the context of a single GCM; they similarly concluded that it was a useful approach. Put differently, because our interest is in the long-term climate response, which is delayed decades to centuries by the ocean's thermal inertia, it is reasonable to allow fast feed- backs to be included in the forcing (as in the RFP method), since these feedbacks are felt as forcings by the ocean and thus affect the long-term climate response (Hansen et al., 2005). This also makes sense from an energy balance perspective (Murphy et al., 2009) and is more suitable in the conceptual framework of radiative forcing and climate sensitivity (Gregory et al., 2004; Knutti and Hegerl, 2008; Quaas et al., 2009a).

For indirect aerosol effects, the advantage of the RFP method over the instantaneous forcing is that it allows the radiative impact of aerosols on both cloud albedo and precipitation efficiency to be evaluated. As shown in Fig. 1, if estimates of other aerosol-cloud interactions are considered in addition to the cloud albedo effect, then these estimates are mostly larger than the cloud albedo effect alone. This suggests that most of the model-calculated additional effects do not offset the cloud albedo effect, but rather constitute an additional cooling. Although the total indirect effect shows more scatter than the cloud albedo effect, more recent estimates indicate weaker values. Some of the weakest estimates result from estimates of the indirect aerosol forcing from satellite data or from general circulation model (GCM) estimates that constrain the indirect aerosol effect using satellite data. Also, some aerosol interactions with mixed-phase clouds can partly offset the forcing due to the cloud albedo effect.

A complementary approach to estimate the total anthropogenic aerosol effect is to infer it as a residual using the observed temperature record over land, and estimates of the ocean heat uptake and the evolution of greenhouse gas and solar radiative forcing (Anderson et al., 2003; Hegerl et al., 2007) (dashed area in Fig. 1). One estimate includes only the indirect aerosol effect in which case additional assumptions about the direct aerosol effect were made (solid black vertical bar in Fig. 1). The total anthropogenic aerosol effect or indirect aerosol effect so derived would, however, also include any other possible hitherto unknown cooling effect, but this is thought to be small. These so-called inverse estimates constrain the total cooling forcing over the 20th century, attributable to anthropogenic aerosols, to a likely range ${ }^{1}$ of -0.1 to $-1.7 \mathrm{~W} \mathrm{~m}^{-2}$ (Hegerl et al., 2007). A total anthropogenic aerosol effect that is more negative than $-1.7 \mathrm{~W} \mathrm{~m}^{-2}$ would thus be inconsistent with the observed warming. An approach that constrains the total cooling effect since 1950 purely from an energy balance perspective limits it to between -0.7 to $-1.5 \mathrm{~W} \mathrm{~m}^{-2}$ (Murphy et al., 2009).

\section{Method}

In this paper we compare the forcings due to two well-mixed greenhouse gases, the direct aerosol forcing and the cloud albedo effect as described in Table 1 from five atmospheric GCMs with the respective RFP that take fast feedbacks and

\footnotetext{
${ }^{1}$ likely refers to a $>66 \%$ probability of occurrence
} 
Table 1. Experimental set-up.

\begin{tabular}{lcc}
\hline Forcing agent & pre-industrial concentration & present-day concentration \\
\hline $\mathrm{CO}_{2}$ & $280 \mathrm{ppm}$ & $379 \mathrm{ppm}$ \\
$\mathrm{CH}_{4}$ & $0.715 \mathrm{ppm}$ & $1.774 \mathrm{ppm}$ \\
direct aerosol effect (DAE) & pre-industrial emissions (1750 or 1860) & present-day (year 2000) emissions \\
cloud albedo effect (IAE) & pre-industrial emissions (1750 or 1860) & present-day (year 2000) emissions \\
\hline
\end{tabular}

interactions into account. Indirect aerosol effects beyond the cloud albedo effect cannot be compared this way because they comprise fast feedbacks and interactions and thus no forcing calculation can be done for them. The versions of the participating GCMs are: CSIRO in low resolution (Rotstayn et al., 2007; Rotstayn and Liu, 2009), EC-Earth (Storelvmo et al., 2009), ECHAM5 (Lohmann et al., 2008), GISS (Menon et al., 2008), and HadGEM2 (Collins et al., 2008). These models vary in the complexity with which they describe aerosol-cloud interactions and thus provide a reasonable spread in radiative forcing and radiative flux perturbation estimates. All models include anthropogenic emissions of sulfate precursors, organic and black carbon. Therefore the direct aerosol effect accounts for black carbon in all models and the semi-direct effect of black carbon is accounted for in the RFP calculations. However, only in the CSIRO and ECHAM5 GCMs does hydrophilic black carbon also contribute to the number of cloud droplets and thus to the cloud albedo effect. The radiative forcing and RFP calculations are conducted by using prescribed sea-surface temperature and sea ice extent, which is also referred to as the Hansen-style method or "quasi-forcing" (Rotstayn and Penner, 2001) to estimate forcing (Hansen et al., 2002).

For the forcing calculations using the traditional forcing definition, denoted $F$, the radiation code of the models was called twice keeping the meteorology fixed. The differences between two radiative transfer calculations due to pre-industrial GHG or aerosol concentrations versus their present-day values were extracted at the top-of-theatmosphere and at the tropopause (or at $100 \mathrm{hPa}$ which some GCMs took as a surrogate for the tropopause). The forcing calculation at the tropopause is the instantaneous value, which does not account for the fast stratospheric temperature adjustment as a response to the warming due to molecular absorption by greenhouse gases (Hansen et al., 1997). Calculation of the adjusted forcing in a GCM would require offline radiative computations or other elaborate procedures (Stuber et al., 2001), so we take the instantaneous value as an approximation to the adjusted value. Results shown in Table 1 of Hansen et al. (2005) suggest that the instantaneous forcing for present-day minus pre-industrial $\mathrm{CO}_{2}$ is roughly $10 \%$ larger than the adjusted forcing $\left(1.55\right.$ and $1.40 \mathrm{~W} \mathrm{~m}^{-2}$ respectively, for a $\mathrm{CO}_{2}$ change from 291 to $370 \mathrm{ppm}$ ). The forcings due to the direct aerosol effect and the cloud albedo effect are obtained from the difference of the forcing calcu- lations in a simulation with present-day and one with preindustrial emissions. Taking the difference between presentday and pre-industrial forcing is necessary as in each simulation the total forcing (present-day minus zero aerosols and pre-industrial minus zero aerosols) is calculated and the zero aerosol forcing needs to be eliminated.

A second set of experiments was then performed to determine the RFP values. The simulations were run for at least 5 years each (some models extended their simulations to 10 years) after a spin-up period of several months under conditions appropriate for the present-day climate, a time scale which allows for all fast feedbacks to fully act. Then annual mean averages over the 5 years (or longer) were used for the analysis. RFP is defined as the difference in global mean net TOA radiative fluxes between two such simulations with the same sea surface temperatures, one with perturbed, and one with unperturbed forcing agents. As the meteorology is different when varying greenhouse concentrations or aerosols, here the radiative effects of the forcing agents will be evaluated as $R F P$, defined as the difference in the net TOA radiation balance between the pre-industrial and present-day simulations.

In cases where GCMs have aerosols that interact with cloud microphysics and where the aerosols are radiatively active at the same time, RFP calculations for individual aerosol effects are more complicated. In these GCMs the interaction between aerosols and cloud droplets is artificially deactivated by prescribing a cloud droplet number concentration for the calculation of precipitation formation in all simulations. For the indirect aerosol effect simulations, aerosol-cloud interactions only affect the radiation calculations. In all other simulations constant cloud droplet and ice crystal number concentrations are used for precipitation formation and radiation calculations. Aerosol optical properties were set to zero for the time integration of all simulations except for the direct effect in order to eliminate the interaction of aerosols with the radiation. For all radiative flux perturbations, the interannual standard deviation is calculated as $\sqrt{2 / n} \times S D_{p}$, where $n$ is the number of years in the simulation and $S D_{p}$ is the pooled standard deviation (Snedecor and Cochran, 1989). 

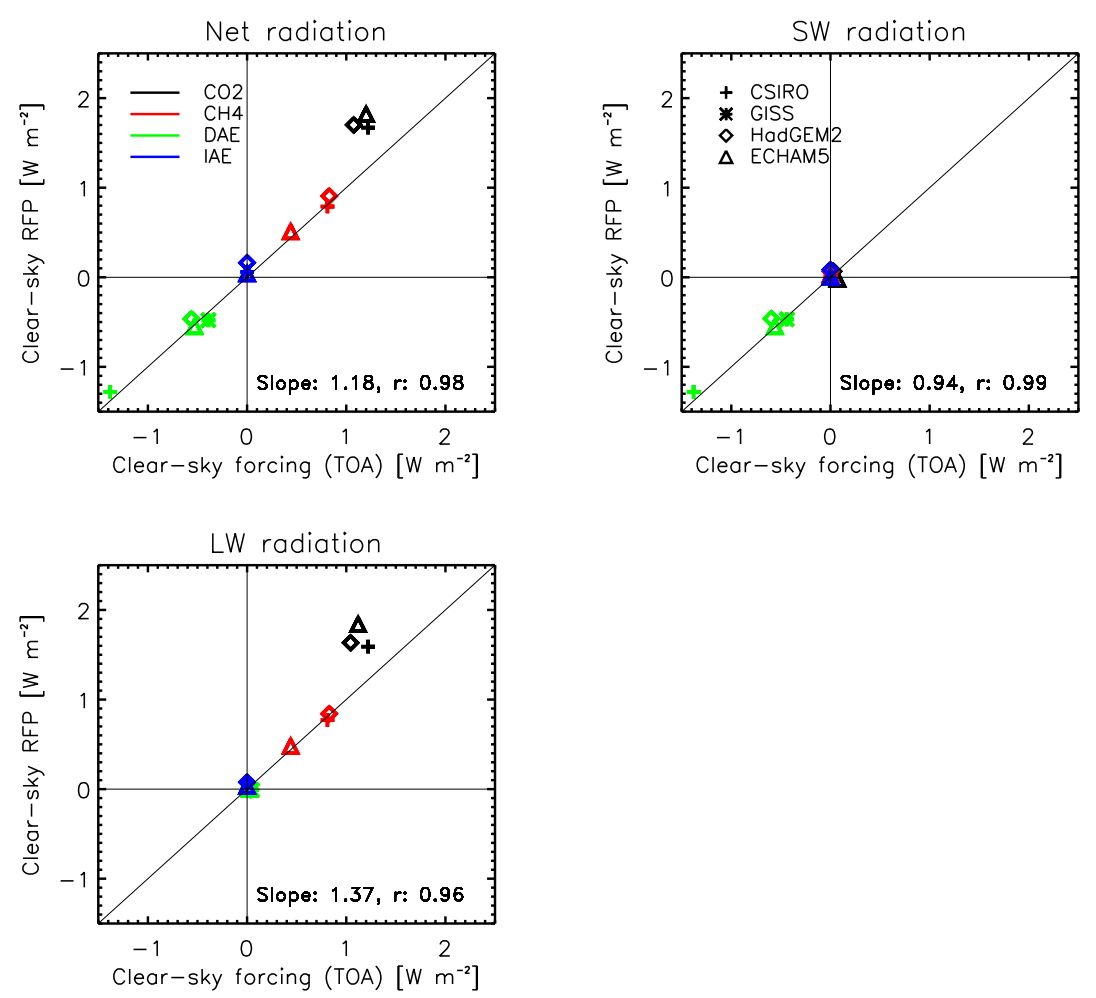

Fig. 3. As Fig. 2, but for the clear-sky net, shortwave and longwave RFP versus TOA $F$ from four GCMs.

\section{Radiative forcing versus radiative flux perturbation}

The estimates of $R F P$ vs. $F$ at TOA and at the tropopause for the different forcing agents from the five GCMs are shown in Fig. 2. The difference between tropopause and TOA forcing is mainly important for $\mathrm{CO}_{2}$, as an increase in $\mathrm{CO}_{2}$ warms the troposphere but cools the stratosphere. If a stratospheric temperature adjustment would have been allowed in these simulations, then $F$ at TOA would equal $F$ at the tropopause (Hansen et al., 1997). Therefore for $\mathrm{CO}_{2}, R F P$ at TOA should rather be compared to $F$ at the tropopause (right panel), which is a reasonable approximation to the adjusted forcing. If the $F$ values in the right panel were reduced by about $10 \%$, to account for omission of the stratospheric adjustment in our runs (Hansen et al., 2005), the slope and the correlation coefficient of the least squares fit through the data would be further improved.

For the majority of these different estimates, the $F$ values for the net radiation at the tropopause fall within the $R F P \pm$ their interannual standard deviation. Deviations occur mainly for the larger forcings (carbon dioxide and the first indirect effect) especially for those models with larger forcings for a given species. For individual models explanations can be found that relate to the way the cloud feedback differs in these simulations. The negative $F$ and RFP values for the aerosol effects and their deviations from the one-to-one line are reflected in the shortwave $F$ and $R F P$ values. The pos- itive $F$ and $R F P$ values for the greenhouse gases and their deviations from the one-to-one line are dominated by their longwave signals (Fig. 2). The scatter plots of $F$ versus RFP also include some earlier literature estimates by Rotstayn and Penner (2001) and Hansen et al. (2005).

The deviation from the 1:1 line in the $\mathrm{CO}_{2} R F P$ vs. forcing at the tropopause may be indicative of a semi-direct cloud response to $\mathrm{CO}_{2}$ forcing (Andrews and Forster, 2008) or it could be due to other feedbacks between the climate system and cloud. We attempt to quantify the semi-direct cloud response. Ideally this should be done in terms of the differences from the 1:1 line in the $\mathrm{CO}_{2} R F P$ vs. forcing at the tropopause for all-sky minus clear-sky conditions. However, as no model saved the clear-sky forcing data at the tropopause, we attempt to estimate the semi-direct cloud response to $\mathrm{CO}_{2}$ forcing from the comparison of the difference in net radiation $(R F P$ - TOA forcing for all-sky conditions ) - (RFP - TOA forcing for clear-sky conditions) assuming that this difference will not be that different at the tropopause and at TOA. The multi-model average amounts to $0.15 \mathrm{~W} \mathrm{~m}^{-2}$, in agreement with the small positive semidirect cloud response to $\mathrm{CO}_{2}$ forcing found by Gregory and Webb (2008). However, Andrews and Forster (2008) also identified a semi-direct effect of $\mathrm{CO}_{2}$ in the clear-sky (e.g., $\mathrm{CO}_{2}$-induced changes in lapse-rate). Given that we lack the appropriate diagnostic to qualify this, we cannot rule out that we see a combination of a semi-direct cloud response to $\mathrm{CO}_{2}$ 

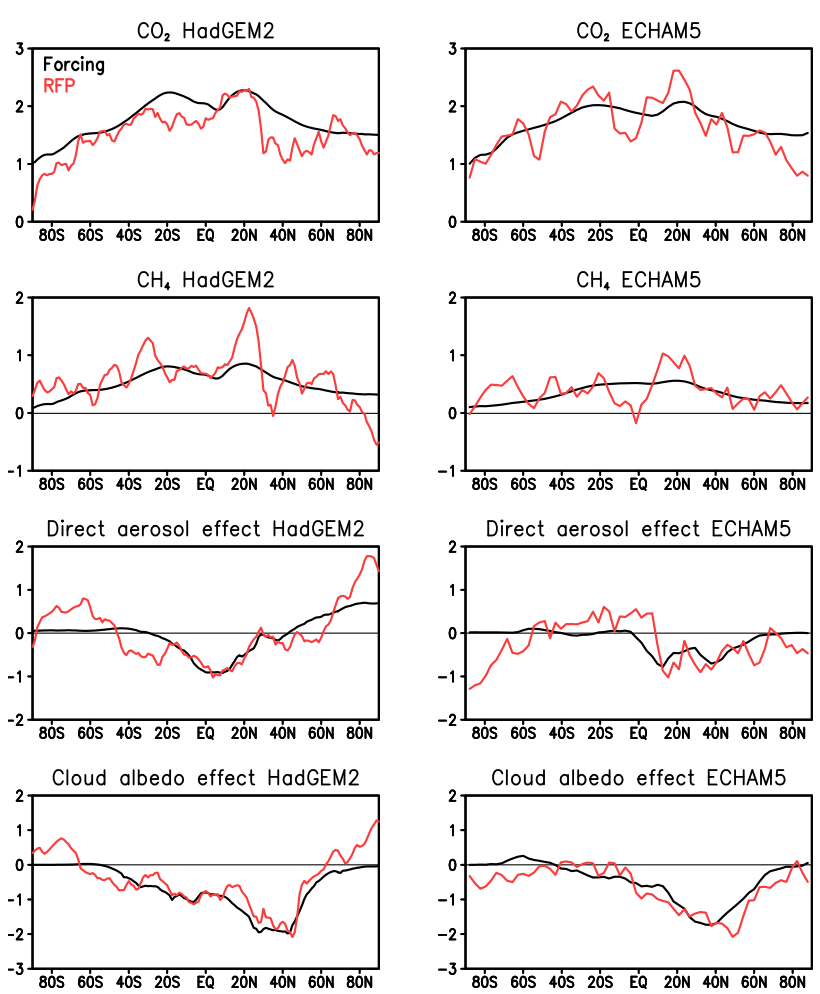

Fig. 4. Annual zonal means of $R F P$ vs. $F\left[\mathrm{~W} \mathrm{~m}^{-2}\right]$ for the different forcing agents from the HadGEM2 and ECHAM5 GCMs.

and a semi-direct effect of $\mathrm{CO}_{2}$ in the clear-sky or any other feedback between clouds and climate.

Deviations between the forcing and $R F P$ estimates are smaller in the clear-sky case where the influence of cloud feedbacks is much smaller (Fig. 3). Unfortunately the clearsky results are only available for the TOA forcing but not for the tropopause forcing. There are no significant changes in precipitation and the hydrological cycle between the forcing and RFP estimates as otherwise there would be differences in the direct and indirect aerosol effect.

Changes in total cloud cover, liquid and ice water path remain below $1 \%$ of their present-day values in all RFP simulations and models (not shown). Also we do not find any strong correlation of the changes in cloud cover, water vapor mass or precipitation with the TOA net radiation changes in the RFP simulations (not shown). Thus, the zonal and annual mean patterns of the RFP estimates are noisy versions of the forcing distributions because of the inclusion of fast interactions (Figs. 4-6). These figures show that the feedbacks in the RFP estimates are not systematic. This makes sense as otherwise we would expect to see systematic deviations from the 1:1 line when regressing the TOA net radiation flux perturbation versus the tropopause forcing in Fig. 2. The only exception occurs for $\mathrm{CO}_{2}$ and the semi-direct cloud response as discussed above. Still, when comparing the RFP estimates and forcings for $\mathrm{CO}_{2}$ in Figs. 4-6 between the different models, one does not see any systematic differences.
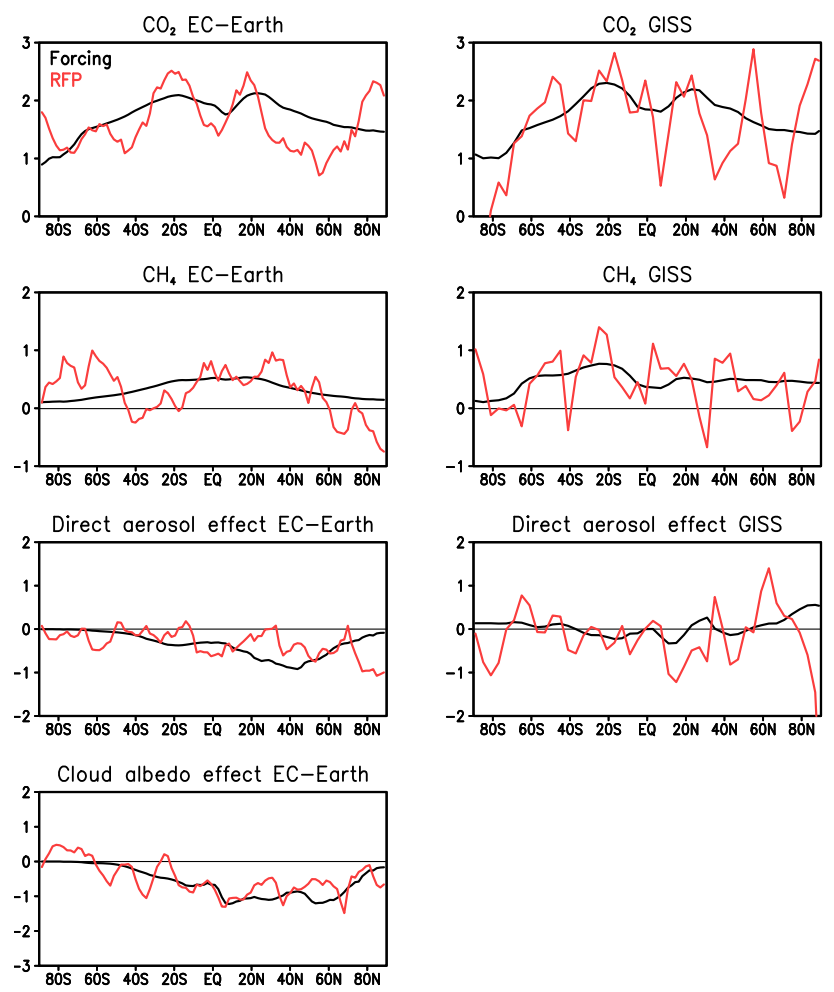

Fig. 5. Annual zonal means of $R F P$ vs. $F\left[\mathrm{~W} \mathrm{~m}^{-2}\right.$ ] for the different forcing agents from the EC-Earth and GISS GCMs.
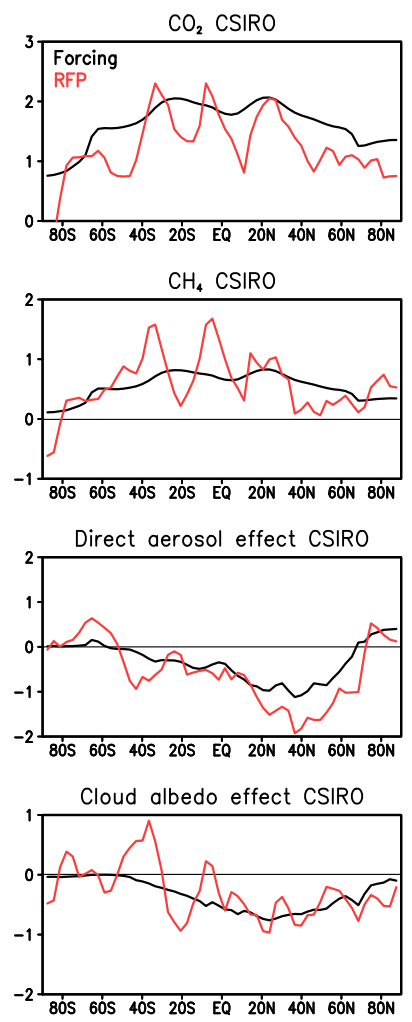

Fig. 6. Annual zonal means of $R F P$ vs. $F\left[\mathrm{~W} \mathrm{~m}^{-2}\right.$ ] for the different forcing agents from the CSIRO GCM. 
The variations of the RFP estimates around the forcings of $\mathrm{CO}_{2}$ differ regionally between the climate models and also the zonal mean patterns for the RFP estimates of $\mathrm{CO}_{2}$ differ from those for $\mathrm{CH}_{4}$.

\section{Conclusions}

In this paper we argue that feedbacks and interactions that are fast as compared to the time scale of global warming should be included when estimating the total anthropogenic aerosol effect. The total anthropogenic aerosol effect cannot be evaluated as a forcing precisely because it includes fast feedbacks and interactions and needs to be obtained from the RFP method. Here we show that the estimates of the tropopause forcing versus the RFP method at the top-of-theatmosphere yield comparable results for the considered forcing agents, $\mathrm{CO}_{2}, \mathrm{CH}_{4}$, the direct aerosol effect and the cloud albedo effect. We showed that the zonal and annual mean pattern of the RFP estimates are a noisy version of the forcing distributions, while they do not differ systematically. The global annual mean values mostly fall within the interannual standard deviation of the RFP simulations.

This is a very powerful result as it shows that RFP estimates are consistent with forcing calculations using the traditional approach for all the species/effects considered here. Extrapolating these findings to the total anthropogenic aerosol effect implies that even though it needs to be obtained from the RFP method, it is nevertheless comparable to the forcings due to well-mixed greenhouse gases.

We thus conclude that assessing different forcing agents with the RFP method is a valid option to be considered in future IPCC reports. Moreover, replacing the global-mean total anthropogenic aerosol forcing by its RFP has its merits because it is the overall anthropogenic aerosol flux perturbation that is needed for the global energy balance (Murphy et al., 2009).

\section{Appendix A}

\section{References for Fig. 1}

\section{A1 Cloud albedo effect}

Kaufman and Chou (1993), Jones et al. (1994), Boucher and Lohmann (1995), Chuang et al. (1997), Feichter et al. (1997), Lohmann and Feichter (1997), Rotstayn (1999), Lohmann et al. (2000), Kiehl et al. (2000), Jones et al. (2001), Williams et al. (2001), Ghan et al. (2001), Rotstayn and Penner (2001), Chuang et al. (2002), Kristjánsson (2002), Rotstayn and Liu (2003), Suzuki et al. (2004), Quaas et al. (2004), Dufresne et al. (2005), Ming et al. (2005), Chen and Penner (2005), Takemura et al. (2005), Quaas and Boucher (2005), Penner et al. (2006), Kvalevag and Myhre (2007), Quaas et al. (2008), Lebsock et al. (2008), Wang and Penner (2009), Storelvmo et al. (2009), Rotstayn and Liu (2009), Haerter et al. (2009)

\section{A2 Total aerosol indirect effect}

\section{A2.1 Cloud albedo and cloud lifetime effect}

Lohmann and Feichter (1997), Rotstayn (1999), Lohmann et al. (2000), Jones et al. (2001), Williams et al. (2001), Ghan et al. (2001), Lohmann and Lesins (2002), Menon et al. (2002), Kristjánsson (2002), Peng and Lohmann (2003), Kristjánsson et al. (2005), Ming et al. (2005), Rotstayn and Liu (2005), Takemura et al. (2005), Quaas et al. (2006), Storelvmo et al. (2006), Storelvmo et al. (2008a), Rotstayn and Liu (2009), Hoose et al. (2009)

\section{A2.2 Cloud albedo, cloud lifetime, direct and semi-direct effect}

Lohmann and Feichter (2001), Penner et al. (2003), Penner et al. (2006), Lohmann et al. (2007), Rotstayn et al. (2007), Posselt and Lohmann (2008), Posselt and Lohmann (2009), Quaas et al. (2009b)

\section{A2.3 Cloud albedo, cloud lifetime, direct effect and aerosol effects on mixed-phase clouds}

Lohmann and Diehl (2006), Jacobson (2006), Storelvmo et al. (2008a), Hoose et al. (2008b), Storelvmo et al. (2008b), Koch et al. (2009), Lohmann and Hoose (2009)

\section{A2.4 Cloud albedo, cloud lifetime, direct effect and aerosol effects on convective clouds}

Menon and Rotstayn (2006), Lohmann (2008), Unger et al. (2009)

\section{A2.5 Inverse estimates of the direct and indirect aerosol effects}

Andronova and Schlesinger (2001), Knutti et al. (2002), Gregory et al. (2002), Forest et al. (2002), Knutti et al. (2003), Forest et al. (2006), Stott et al. (2006), Shindell and Faluvegi (2009), Murphy et al. (2009)

Acknowledgements. We would like to thank Piers Forster, Yi Ming, Steven Schwartz, William Collins, Sandrine Bony, Leo Donner and other participants of the FIAS workshop on "Clouds in the perturbed climate system" in March 2008 for useful discussions and Sylvaine Ferrachat for technical help. We thank the three anonymous referees for useful suggestions. UL was supported by NCCR Climate and by CSCS. SM was supported by the Office of Science at the US DOE under Contract No. DE-AC02-05CH11231. SM and DK acknowledge support from the NASA MAP program. AJ was supported by the Joint DECC and Defra Integrated Climate Programme - DECC/Defra (GA01101). LR was supported in part by ACCSP.

Edited by: Y. Balkanski 


\section{References}

Anderson, T. L., Charlson, R. J., Schwartz, S. E., Knutti, R., Boucher, O., Rodhe, H., and Heintzenberg, J.: Climate forcing by Aerosols - a hazy picture, Science, 300, 1103-1104, 2003.

Andrews, T. and Forster, P. M.: $\mathrm{CO}_{2}$ forcing induces semi-direct effects with consequences for climate feedback interpretations, Geophys. Res. Lett., 35, doi: 10.1029/2007GL032 273, 104802, 2008.

Andronova, N. G. and Schlesinger, M. E.: Objective estimation of the probability density function for climate sensitivity, J. Geophys. Res., 106, 22605-22611, 2001.

Boucher, O. and Lohmann, U.: The sulfate-CCN-cloud albedo effect: A sensitivity study with two general circulation models, Tellus B, 47, 281-300, 1995.

Chen, Y. and Penner, J. E.: Uncertainty analysis for estimates of the first indirect aerosol effect, Atmos. Chem. Phys., 5, 2935-2948, 2005 , http://www.atmos-chem-phys.net/5/2935/2005/.

Chuang, C. C., Penner, J. E., Taylor, K. E., Grossmann, A. S., and Walton, J. J.: An assessment of the radiative effects of anthropogenic sulfate, J. Geophys. Res., 102, 3761-3778, 1997.

Chuang, C. C., Penner, J. E., Prospero, J. M., Grant, K. E., Rau, G. H., and Kawamoto, K.: Cloud susceptibility and the first aerosol indirect forcing: Sensitivity to black carbon and aerosol concentrations, J. Geophys. Res., 107, 4564, doi:10.1029/2000JD000215, 2002.

Collins, W. J., Bellouin, N., Doutriaux-Boucher, M., Gedney, N., Hinton, T., Jones, C. D., Liddicoat, S., Martin, G., O'Connor, F., Rae, J., Senior, C., Totterdell, I., Woodward, S., Reichler, T., Kim, J., and Halloran, P.: Evaluation of the HadGEM2 model, Tech. rep., Hadley Cent. Tech. Note 74, Met Office, Exeter, UK, 2008.

Denman, K., Brasseur, G., Chidthaisong, A., Ciais, P., Cox, P., Dickinson, R., Hauglustaine, D., Heinze, C., Holland, E., Jacob, D., Lohmann, U., Ramachandran, S., Silva Dias, P., Wofsy, S., and Zhang, X.: Couplings between changes in the climate system and biogeochemistry, in Climate Change 2007: The Physical Science Basis. Contribution of Working Group I to the Fourth Assessment Report of the Intergovernmental Panel on Climate Change, edited by S. Solomon, D. Qin, M. Manning, Z. Chen, M. Marquis, K. B. Averyt, M. Tignor, and H. L. Miller, pp. 499588, Cambridge Univ. Press, Cambridge, United Kingdom and New York, NY, USA, 2007.

Dufresne, J. L., Quaas, J., Boucher, O., Denvil, S., and Fairhead, L.: Contrasts in the effects on climate of anthropogenic sulfate aerosols between the 20th and the 21st century, Geophys. Res. Lett., 32, doi:10.1029/2005GL023619, 121703, 2005.

Feichter, J., Lohmann, U., and Schult, I.: The atmospheric sulfur cycle and its impact on the shortwave radiation, Clim. Dyn., 13, 235-246, 1997.

Forest, C. E., Stone, P. H., Sokolev, A. P., Allen, M. R., and Webster, M. D.: Quantifying uncertainties in climate system properties with the use of recent climate observations, Science, 295, 113$117,2002$.

Forest, C. E., Stone, P. H., and Sokolov, A. P.: Estimated PDFs of climate system properties including natural and anthropogenic forcings, Geophys. Res. Lett., 33, doi:10.1029/2005GL023977, 101705, 2006.

Forster, P., Ramaswamy, V., Artaxo, P., Berntsen, T., Betts, R., Fa- hey, D. W., Haywood, J., Lean, J., Lowe, D. C., Myhre, G., Nganga, J., Prinn, R., Raga, G., Schulz, M., and Van Dorland, R.: Radiative Forcing of Climate Change, in Climate Change 2007: The Physical Science Basis. Contribution of Working Group I to the Fourth Assessment Report of the Intergovernmental Panel on Climate Change, edited by S. Solomon, D. Qin, M. Manning, Z. Chen, M. Marquis, K. B. Averyt, M. Tignor, and H. L. Miller, pp. 129-234, Cambridge Univ. Press, Cambridge, United Kingdom and New York, NY, USA, 2007.

Forster, P. M. D. and Taylor, K. E.: Climate forcings and climate sensitivities diagnosed from coupled climate model integrations, J. Climate, 19, 6181-6194, 2006.

Ghan, S. J., Easter, R. C., Hudson, J., and Bréon, F.-M.: Evaluation of aerosol indirect radiative forcing in MIRAGE, J. Geophys. Res., 106, 5317-5334, 2001.

Gregory, J. and Webb, M.: Tropospheric Adjustment Induces a Cloud Component in $\mathrm{CO}_{2}$ Forcing, J. Climate, 21, 58-71, 2008.

Gregory, J. M., Stouffer, R. J., Raper, S. C. B., Stott, P. A., and Rayner, N. A.: An observationally based estimate of the climate sensitivity, J. Climate, 15, 3117-3121, 2002.

Gregory, J. M., Ingram, W. J., Palmer, M. A., Jones, G. S., Stott, P. A., Thorpe, R. B., Lowe, J. A., Johns, T. C., and Williams, K. D.: A new method for diagnosing radiative forcing and climate sensitivity, Geophys. Res. Lett., 31, doi:10.1029/2003GL018747, 103205, 2004.

Haerter, J. O., Roeckner, E., Tomassini, L., and von Storch, J. S.: Parametric uncertainty effects on aerosol radiative forcing, Geophys. Res. Lett., 36, doi:10.1029/2009GL039050, 115707, 2009.

Hansen, J., Sato, M., and Ruedy, R.: Radiative forcing and climate response, J. Geophys. Res., 102, 6831-6864, 1997.

Hansen, J., , Sato, M., Nazarenko, L., Ruedy, R., Lacis, A., Koch, D., Tegen, I., Hall, T., Shindell, D., Santer, B., Stone, P., Novakov, T., Thomason, L., Wang, R., Wang, Y., Jacob, D., Hollandsworth, S., Bishop, L., Logan, J., Thompson, A., Stolarski, R., Lean, J., Willson, R., Levitus, S., Antonov, J., Rayner, N., Parker, D., and Christy, J.: Climate forcings in Goddard Institute for Space Studies SI2000 simulations, J. Geophys. Res., 107, doi:10.1029/2001JD001143, 4347, 2002.

Hansen, J., Sato, M., Ruedy, R., Nazarenko, L., Lacis, A., Schmidt, G. A., Russell, G., Aleinov, I., Bauer, M., Bauer, S., Bell, N., Cairns, B., Canuto, V., Chandler, M., Cheng, Y., Del Genio, A., Faluvegi, G., Fleming, E., Friend, A., Hall, T., Jackman, C., Kelley, M., Kiang, N., Koch, D., Lean, J., Lerner, J., Lo, K., Menon, S., Miller, R., Minnis, P., Novakov, T., Oinas, V., Perlwitz, J., Perlwitz, J., Rind, D., Romanou, A., Shindell, D., Stone, P., Sun, S., Tausnev, N., Thresher, D., Wielicki, B., Wong, T., Yao, M., and Zhang, S.: Efficacy of climate forcings, J. Geophys. Res., 110, doi:10.1029/2005JD005776, d18104, 2005.

Haywood, J. and Schulz, M.: Causes of the reduction in uncertainty in the anthropogenic radiative forcing of climate between IPCC (2001) and IPCC (2007), Geophys. Res. Lett., 34, doi:10.1029/2007GL030749, 120701, 2007.

Haywood, J. M., Donner, L. J., Jones, A., and Golaz, J.-C.: Global indirect radiative forcing caused by aerosols: IPCC (2007) and beyond, in Clouds in the Perturbed Climate System, edited by J. Heintzenberg and R. J. Charlson, pp. 451-467, MIT Press, Cambridge, 2009.

Hegerl, G. C., Zwiers, F. W., Braconnot, P., Gillett, N. P., Luo, Y., Orsini, J. A. M., Nicholls, N., Penner, J. E., and Stott, P. A.: Un- 
derstanding and attributing climate change, in Climate Change 2007: The Physical Science Basis. Contribution of Working Group I to the Fourth Assessment Report of the Intergovernmental Panel on Climate Change, edited by S. Solomon, D. Qin, M. Manning, Z. Chen, M. Marquis, K. B. Averyt, M. Tignor, and H. L. Miller, pp. 663-746, Cambridge Univ. Press, Cambridge, United Kingdom and New York, NY, USA, 2007.

Hoose, C., Lohmann, U., Erdin, R., and Tegen, I.: Global influence of dust mineralogical composition on heterogeneous ice nucleation in mixed-phase clouds, Environ. Res. Lett., 3, 025003, doi:10.1088/1748-9326/3/2/025003, 2008b.

Hoose, C., Kristjánsson, J. E., Iversen, T., Kirkevåg, A., Seland, Ø., and Gettelman, A.: Constraining cloud droplet number concentration in GCMs suppresses the aerosol indirect effect, Geophys. Res. Lett., 36, doi:10.1029/2009GL038568, 112807, 2009.

Jacobson, M. Z.: Effects of Externally-Through-Internally-Mixed Soot Inclusions within Clouds and Precipitation on Global Climate, J. Phys. Chem., 110, 6860-6873, 2006.

Jones, A., Roberts, D. L., and Slingo, A.: A climate model study of indirect radiative forcing by anthropogenic sulphate aerosols, Nature, 370, 450-453, 1994.

Jones, A., Roberts, D. L., Woodage, M. J., and Johnson, C. E.: Indirect sulphate aerosol forcing in a climate model with an interactive sulphur cycle, J. Geophys. Res., 106, 20293-20310, 2001.

Joshi, M., Shine, K., Ponater, M., Stuber, N., Sausen, R., and Li, L.: A comparison of climate response to different radiative forcings in three general circulation models: towards an improved metric of climate change, Clim. Dyn., 20, 843-854, 2003.

Kaufman, Y. J. and Chou, M. D.: Model simulations of the competing climatic effects of $\mathrm{SO}_{2}$ and $\mathrm{CO}_{2}$, J. Climate, 6, 1241-1252, 1993.

Kiehl, J. T.: Twentieth century climate model response and climate sensitivity, Geophys. Res. Lett., 34, doi:10.1029/2007GL031383, 112807, 2007.

Kiehl, J. T., Schneider, T. L., Rasch, P. J., Barth, M. C., and Wong, J.: Radiative forcing due to sulfate aerosols from simulations with the National Center for Atmospheric Research Community Climate Model, Version 3, J. Geophys. Res., 105, 1441-1457, 2000.

Knutti, R. and Hegerl, G. C.: The equilibrium sensitivity of the Earth's temperature to radiation changes, Nature Geosci., 1, 735743, 2008.

Knutti, R., Stocker, T. F., Joos, F., and Plattner, G.-K.: Constraints on radiative forcing and future climate change from observations and climate model ensembles, Nature, 416, 719-723, 2002.

Knutti, R., Stocker, T. F., Joos, F., and Plattner, G. K.: Probabilistic climate change projections using neural networks, Clim. Dyn., 21, 257-272, 2003.

Koch, D., Menon, S., Del Genio, A., Ruedy, R., Aleinov, I., and Schmidt, G. A.: Distinguishing aerosol impacts on climate over the past century, J. Climate, 22, 2659-2677, 2009.

Kristjánsson, J. E.: Studies of the aerosol indirect effect from sulfate and black carbon aerosols, J. Geophys. Res., 107, doi:10.1029/2001JD000887, 4246, 2002.

Kristjánsson, J. E., Iversen, T., Kirkevåg, A., Seland, Ø., and Debernard, J.: Response of the climate system to aerosol direct and indirect forcing: Role of cloud feedbacks, J. Geophys. Res., 110, doi:10.1029/2005JD006299, d24206, 2005.

Kvalevag, M. M. and Myhre, G.: Human impact on direct and diffuse solar radiation during the industrial era, J. Climate, 20, 4874-4883, 2007.

Lebsock, M. D., Stephens, G. L., and Kummerow, C.: Multisensor satellite observations of aerosol effects on warm clouds, J. Geophys. Res., 113, doi:10.1029/2008JD009876, d15205, 2008.

Lohmann, U.: Global anthropogenic aerosol effects on convective clouds in ECHAM5-HAM, Atmos. Chem. Phys., 8, 2115-2131, 2008 ,

http://www.atmos-chem-phys.net/8/2115/2008/.

Lohmann, U. and Diehl, K.: Sensitivity studies of the importance of dust ice nuclei for the indirect aerosol effect on stratiform mixedphase clouds, J. Atmos. Sci, 63, 968-982, 2006.

Lohmann, U. and Feichter, J.: Impact of sulfate aerosols on albedo and lifetime of clouds: A sensitivity study with the ECHAM GCM, J. Geophys. Res., 102, 13685-13700, 1997.

Lohmann, U. and Feichter, J.: Can the direct and semi-direct aerosol effect compete with the indirect effect on a global scale?, Geophys. Res. Lett., 28, 159-161, 2001.

Lohmann, U. and Feichter, J.: Global indirect aerosol effects: a review, Atmos. Chem. Phys., 5, 715-737, 2005, http://www.atmos-chem-phys.net/5/715/2005/.

Lohmann, U. and Hoose, C.: Sensitivity studies of different aerosol indirect effects in mixed-phase clouds, Atmos. Chem. Phys., 9, 8917-8934, 2009, http://www.atmos-chem-phys.net/9/8917/2009/.

Lohmann, U. and Lesins, G.: Stronger constraints on the anthropogenic indirect aerosol effect, Science, 298, 1012-1016, 2002.

Lohmann, U., Feichter, J., Penner, J. E., and Leaitch, W. R.: Indirect effect of sulfate and carbonaceous aerosols: A mechanistic treatment, J. Geophys. Res., 105, 12193-12206, 2000.

Lohmann, U., Stier, P., Hoose, C., Ferrachat, S., Kloster, S., Roeckner, E., and Zhang, J.: Cloud microphysics and aerosol indirect effects in the global climate model ECHAM5-HAM, Atmos. Chem. Phys., 7, 3425-3446, 2007,

http://www.atmos-chem-phys.net/7/3425/2007/.

Lohmann, U., Spichtinger, P., Jess, S., Peter, T., and Smit, H.: Cirrus cloud formation and ice supersaturated regions in a global climate model, Env. Res. Lett., 3, doi:10.1088/17489326/3/4/045022, 045022, 2008.

Menon, S. and Rotstayn, L.: The radiative influence of aerosol effects on liquid-phase cumulus and stratiform clouds based on sensitivity studies with two climate models, Climate Dyn., 27, 345-356, 2006.

Menon, S., DelGenio, A. D., Koch, D., and Tselioudis, G.: GCM Simulations of the Aerosol Indirect Effect: Sensitivity to Cloud Parameterization and Aerosol Burden, J. Atmos. Sci., 59, 692713, 2002.

Menon, S., Del Genio, A. D., Kaufman, Y., Bennartz, R., Koch, D., Loeb, N., and Orlikowski, D.: Analyzing signatures of aerosolcloud interactions from satellite retrievals and the GISS GCM to constrain the aerosol indirect effect, J. Geophys. Res., 113, doi:10.1029/2007JD009442, d14s22, 2008.

Ming, Y., Ramaswamy, V., Ginoux, P. A., Horowitz, L. W., and Russell, L. M.: Geophysical Fluid Dynamics Laboratory general circulation model investigation of the indirect radiative effects of anthropogenic sulfate aerosol, J. Geophys. Res., 110, doi:10.1029/2005JD006161, d22206, 2005.

Murphy, D. M., Solomon, S., Portmann, R. W., Rosenlof, K. H., Forster, P. M. d. F., and Wong, T.: An observationally based en- 
ergy balance for the Earth since 1950, J. Geophys. Res., 114, doi:10.1029/2009JD012105, d17107, 2009.

Peng, Y. and Lohmann, U.: Sensitivity study of the spectral dispersion of the cloud droplet size distribution on the indirect aerosol effect, Geophys. Res. Lett., 30, doi:10.1029/2003GL017192, 1507, 2003.

Penner, J. E., Zhang, S. Y., and Chuang, C. C.: Soot and smoke aerosol may not warm climate, J. Geophys. Res., 108, doi:10.1029/2003JD003409, 4657, 2003.

Penner, J. E., Quaas, J., Storelvmo, T., Takemura, T., Boucher, O., Guo, H., Kirkevåg, A., Kristjánsson, J. E., and Seland, Ø.: Model intercomparison of indirect aerosol effects, Atmos. Chem. Phys., 6, 3391-3405, 2006, http://www.atmos-chem-phys.net/6/3391/2006/.

Posselt, R. and Lohmann, U.: Influence of Giant CCN on warm rain processes in the ECHAM5 GCM, Atmos. Chem. Phys., 8, 37693788, 2008, http://www.atmos-chem-phys.net/8/3769/2008/.

Posselt, R. and Lohmann, U.: Sensitivity of the total anthropogenic aerosol effect to the treatment of rain in a global climate model, Geophys. Res. Lett., 36, doi:10.1029/2008GL035796, 102805, 2009.

Quaas, J. and Boucher, O.: Constraining the first aerosol indirect radiative forcing in the LMDZ GCM using POLDER and MODIS satellite data, Geophys. Res. Lett, 32, doi:10.1029/2005GL023850, 117814, 2005.

Quaas, J., Boucher, O., and Bréon, F.-M.: Aerosol indirect effects in POLDER satellite data and the Laboratoire de Météorologie Dynamique-Zoom (LMDZ) general circulation model, J. Geophys. Res., 109, doi:10.1029/2003JD004317, d08205, 2004.

Quaas, J., Boucher, O., and Lohmann, U.: Constraining the total aerosol indirect effect in the LMDZ and ECHAM4 GCMs using MODIS satellite data, Atmos. Chem. Phys., 6, 947-955, 2006, http://www.atmos-chem-phys.net/6/947/2006/.

Quaas, J., Boucher, O., Bellouin, N., and Kinne, S.: Satellite-based estimate of the direct and indirect aerosol climate forcing, J. Geophys. Res., 113, doi:10.1029/2007JD008962, d05204, 2008.

Quaas, J., Bony, S., Collins, W. D., Donner, L., Illingworth, A., Jones, A., Lohmann, U., Satoh, M., Schwartz, S. E., Tao, W.-K., and Wood, R.: Quantification of Clouds in the Changing Climate System and Strategies for Reducing Critical Uncertainties, in Clouds in the perturbed climate system, edited by J. Heintzenberg and R. J. Charlson, pp. 557-573, MIT press, 2009a.

Quaas, J., Ming, Y., Menon, S., Takemura, T., Wang, M., Penner, J. E., Gettelman, A., Lohmann, U., Bellouin, N., Boucher, O., Sayer, A. M., Thomas, G. E., McComiskey, A., Feingold, G., Hoose, C., Kristjánsson, J. E., Liu, X., Balkanski, Y., Donner, L. J., Ginoux, P. A., Stier, P., Grandey, B., Feichter, J., Sednev, I., Bauer, S. E., Koch, D., Grainger, R. G., Kirkevåg, A., Iversen, T., Seland, Ø., Easter, R., Ghan, S. J., Rasch, P. J., Morrison, H., Lamarque, J.-F., Iacono, M. J., Kinne, S., and Schulz, M.: Aerosol indirect effects general circulation model intercomparison and evaluation with satellite data, Atmos. Chem. Phys., 9, 8697-8717, 2009,

http://www.atmos-chem-phys.net/9/8697/2009/.

Ramanathan, V., Crutzen, P. J., Kiehl, J. T., and Rosenfeld, D.: Aerosols, climate and the hydrological cycle, Science, 294, 2119-2124, 2001.

Rotstayn, L. D.: Indirect forcing by anthropogenic aerosols: A global climate model calculation of the effective radius and cloud lifetime effects, J. Geophys. Res., 104, 9369-9380, 1999.

Rotstayn, L. D. and Liu, Y.: Sensitivity of the first indirect aerosol effect to an increase of cloud droplet spectral dispersion with droplet number concentration, J. Climate, 16, 3476-3481, 2003.

Rotstayn, L. D. and Liu, Y.: A smaller global estimate of the second indirect aerosol effect, Geophys. Res. Lett., 32, doi:10.1029/2004GL021922, 105708, 2005.

Rotstayn, L. D. and Liu, Y.: Cloud droplet spectral dispersion and the indirect aerosol effect: Comparison of two treatments in a GCM, Geophys. Res. Lett., 36, doi:10.1029/2009GL038216, 110801, 2009.

Rotstayn, L. D. and Penner, J. E.: Indirect aerosol forcing, quasiforcing, and climate response, J. Climate, 14, 2960-2975, 2001.

Rotstayn, L. D., Cai, W. J., Dix, M. R., Farquhar, G. D., Feng, Y., Ginoux, P., Herzog, M., Ito, A., Penner, J. E., Roderick, M. L., and Wang, M. H.: Have Australian rainfall and cloudiness increased due to the remote effects of Asian anthropogenic aerosols?, J. Geophys. Res., 112, doi:10.1029/2006JD007712, d09202, 2007.

Shindell, D. and Faluvegi, G.: Climate response to regional radiative forcing during the twentieth century, Nature Geosci., 2, 294 300, 2009.

Shine, K., Fouquart, Y., Ramaswamy, V., Solomon, S., and Srinivasan, J.: Radiative forcing, in Radiative Forcing of Climate Change and an Evaluation of the IPCC IS92 Emission Scenarios, edited by J. Houghton, L. Meira Filho, J. Bruce, H. Lee, B. Callander, N. Harris, and K. Maskell, pp. 163-203, Cambridge University Press, Cambridge, United Kingdom and New York, NY, USA, 1995.

Shine, K. P., Cook, J., Highwood, E. J., and Joshi, M. M.: An alternative to radiative forcing for estimating the relative importance of climate change mechanisms, Geophys. Res. Lett., 30, doi:10.1029/2003GL018141, 2047, 2003.

Snedecor, G. W. and Cochran, W. G.: Statistical methods, Blackwell Publishing, Iowa, USA, 8. Edn., 1989.

Storelvmo, T., Kristjánsson, J. E., Ghan, S. J., Kirkevåg, A., Seland, $\varnothing$. , and Iversen, T.: Predicting cloud droplet number concentration in Community Atmosphere Model (CAM)-Oslo, J. Geophys. Res., 111, doi:10.1029/2005JD006300, d24208, 2006.

Storelvmo, T., Kristjánsson, J.-E., and Lohmann, U.: Aerosol influence on mixed-phase clouds in CAM-Oslo, J. Atmos. Sci., 65, 3214-3230, 2008a.

Storelvmo, T., Kristjánsson, J. E., Lohmann, U., Iversen, T., Kirkevåg, A., and Seland, Ø.: Modeling of the WegenerBergeron-Findeisen process - implications for aerosol indirect effects, Env. Res. Lett., 3, doi:10.1088/1748-9326/3/4/045001, 045001, 2008b.

Storelvmo, T., Lohmann, U., and Bennartz, R.: What governs the spread in shortwave forcings in the transient IPCC AR4 models?, Geophys. Res. Lett., 36, doi:10.1029/2008GL036069, 101806, 2009.

Stott, P. A., Mitchell, J. F. B., Allen, M. R., Delworth, T. L., Gregory, J. M., Meehl, G. A., and Santer, B. D.: Observational constraints on past attributable warming and predictions of future global warming, J. Climate, 19, 3055-3069, 2006.

Stuber, N., Sausen, R., and Ponater, M.: Stratosphere adjusted radiative forcing calculations in a comprehensive climate model, Theor. Appl. Climatol., 68, 125-135, 2001. 
Suzuki, K., Nakajima, T., Numaguti, A., Takemura, T., Kawamoto, K., and Higurashi, A.: A study of the aerosol effect on a cloud field with simultaneous use of GCM modeling and satellite observations, J. Atmos. Sci., 61, 179-194, 2004.

Takemura, T., Nozawa, T., Emori, S., Nakajima, T. Y., and Nakajima, T.: Simulation of climate response to aerosol direct and indirect effects with aerosol transport-radiation model, J. Geophys. Res., 110, doi:10.1029/2004JD00502, d02202, 2005.

Twomey, S. A.: The influence of pollution on the shortwave albedo of clouds, J. Atmos. Sci., 34, 1149-1152, 1977.
Unger, N., Menon, S., Koch, D. M., and Shindell, D. T.: Impacts of aerosol-cloud interactions on past and future changes in tropospheric composition, Atmos. Chem. Phys., 9, 4115-4129, 2009, http://www.atmos-chem-phys.net/9/4115/2009/.

Wang, M. and Penner, J. E.: Aerosol indirect forcing in a global model with particle nucleation, Atmos. Chem. Phys., 9, 239-260, 2009 , http://www.atmos-chem-phys.net/9/239/2009/.

Williams, K. D., Jones, A., Roberts, D. L., Senior, C. A., and Woodage, M. J.: The response of the climate system to the indirect effects of anthropogenic sulfate aerosols, Clim. Dyn., 17, 845-856, 2001. 